\title{
Nutritional stability of instant Kunun zaki flours produced from millet- malted cowpea and millet-malted soybean during the 3 months storage
}

\author{
${ }^{1}$ Eneke, B.M. ${ }^{2 *}$ Attaugwu, R.N. ${ }^{1}$ Ufondu, H.E. and ${ }^{1}$ Uvere, P.O. \\ ${ }^{1}$ Department of Food Science and Technology, University of Nigeria, Nsukka. Nigeria 410001 \\ ${ }^{2}$ Department of Food Science and Technology, Madonna University Nigeria, Akpugo, Enugu state Nigeria
}

\author{
Article history: \\ Received: 2 August 2017 \\ Received in revised form: 28 \\ August 2017 \\ Accepted: 31 August 2017 \\ Available Online: 1 \\ September 2017
}

Keywords:

Kunun zaki,

Instant,

Nutritional content,

Stability

DOI:

https://doi.org/10.26656/fr.2017.2(1).115

\begin{abstract}
The study investigated the changes in crude protein content, moisture, fat, total sugar, and thiobarbituric acid (TBA) value) of instant Kunun zaki powder packaged in polyethylene and stored for 90 days. Instant Kunun zaki powder was prepared from millet-cowpea malt $\left(\mathrm{MC}_{\mathrm{m}}\right)$ and millet-soybean malt $\left(\mathrm{MS}_{\mathrm{m}}\right)$ by steam heating, packaged in polypropylene $(12 \times 18 \mathrm{~cm})$, sealed and stored at room temperature $\left(28 \pm 0.3^{\circ} \mathrm{C}\right)$ and room humidity $(45 \%)$ for 90 days during which the chemical properties were monitored every 30 days using standard procedures. The moisture content of $\mathrm{MC}_{\mathrm{m}}$ and $\mathrm{MS}_{\mathrm{m}}$ increased by 66.61 and $65.77 \%$; the sugar increased by $28.90 \%$ and $11.33 \%$; the fat content increased by 0.21 and $0.45 \%$; the TBA content of $\mathrm{MC}_{\mathrm{m}}$ and $\mathrm{MS}_{\mathrm{m}}$ increased by 0.0002 and $0.0001 \mathrm{mg} / 100 \mathrm{~g}$ while the protein content decreased by $15.56 \%$ and $17.07 \%$ respectively. The study has revealed that storage of instant Kunun zaki flours in flexible packaging material at ambient temperature resulted in an increase in the chemical parameters except for protein which decreased hence there would be needed to use a better material for storage.
\end{abstract}

\section{Introduction}

Kunun zaki is a non-carbonated traditional beverage in Northern Nigeria produced from millet (Pennisetum typhoideum), although other cereal grains and optional ingredients are often added for a variety of reasons (Adeyemi and Umar, 1994; Effiuvwevwere and Akoma, 1995; Gaffa and Ayo, 2002). The traditional production of Kunun zaki has been modified to make it more shelf stable and to shorten the production time (from 24 hours to 12 hours) (Gaffa and Ayo, 2002). Traditionally, Kunun zaki is produced by steeping the grains in water, wet milling with spices and sieving, the overall process taking 24 hours (Adeyemi and Umar, 1994). This traditional method has been improved by shortening the processing time to 12 hours by steeping the grains in warm water containing $15 \%$ sodium metabisulphite, wetmilling, liquefication and saccharification with enzymes in the grain, filtering, bottling and pasteurization at $80 \mathrm{oC}$ for 30 minutes before refrigeration at $4-8^{\circ} \mathrm{C}$ (Gaffa and Ayo, 2002). Traditionally produced Kunun zaki has a shelf life of about 24 hours (Adeyemi and Umar, 1994) at ambient temperature. The improved method can, however, extend the shelf life to 8 days after pasteurization followed by refrigeration storage
(Osuntogun and Aboada, 2004) which can last for 90 days when chemical preservation is applied as has been achieved by FIIRO, Nigeria (Haard, 1998). Also, instant Kunun zaki flour has been produced by Dala Foods Limited Kano, Nigeria and commercialized Kunun Tsamiya, the product is made only from millet.

Work on the shelf-life extension of traditional Kunun zaki (Haard, 1998; Osuntogun and Aboada, 2004) yielded products with a maximum shelf life of 90 days but Dala Foods, Kano, Nigeria produced millet flour in a re-constitutable form. The production of instant Kunun zaki flours from millet and malts of cowpea and soybean (Uvere and Amazikwu, 2011; Uvere et al., 2011) improved the protein content, but the peroxide value and thiobarbituric acid value were very high pointing to a possible instability during storage. This work was therefore carried out to study the changes in chemical properties of the flours packaged in polyethylene and stored at room temperature $\left(28 \pm 0.3^{\circ} \mathrm{C}\right)$ and room humidity $(\mathrm{RH}=45 \%)$ for 90 days. (Nov-Jan, 2009).

\section{Materials and methods}

2.1 Materials 
Millet (Pennisetum typhoideum), cowpea (Vigna unguiculata), soybean (Glycine max) and ginger (Zingiber officinale) were purchased from Nsukka main market, Enugu State, Nigeria. Polypropylene used for packaging was obtained from the Department of Food Science and Technology Laboratories, University of Nigeria, Nsukka.

\subsection{Methods}

Instant Kunun zaki powder was prepared from millet -cowpea malt and millet-soybean malt as described by Uvere et al. (2011).

\subsubsection{Storage studies}

The instant Kunun zaki flours were packaged in polypropylene $(12 \times 18 \mathrm{~cm})$, sealed and stored at room temperature $\left(28 \pm 0.3^{\circ} \mathrm{C}\right)$ for 90 days during which the crude protein content was determined by the microKjeldahl procedure of the AOAC (2010). Moisture and fat contents were determined as described by Kirk and Sawyer (1991), total sugar, by the acid hydrolysis method of Radley (1976), while thiobarbituric acid (TBA) value was by the method of Tarladgis et al. (1960). Determinations were carried out in triplicate and the error reported as standard deviations from the mean. Data were subjected to one-way ANOVA; Duncan's New Multiple Range Test (Duncan, 1995) was used to separate the means for each treatment. Significance was accepted at $\mathrm{p}<0.05$ level.

\section{Results}

\subsection{Moisture}

Millet (M) had the highest moisture content of $6.55 \%$; other values were $6.13 \%$ for millet-cowpea (MC), $6.43 \%$ in millet-soybean (MS), $6.23 \%$ in milletmalted cowpea $\left(\mathrm{MC}_{\mathrm{m}}\right)$ and $6.34 \%$ in millet-malted soybean $\left(\mathrm{MS}_{\mathrm{m}}\right)$. On storage, (Figure 1) the moisture content of all the samples increased; the amount of moisture absorbed between months decreased with storage time; between months 0 and 1 , the values were $3.45,3.82,3.79 .4 .09$ and $4.02 \mathrm{~g} / 100 \mathrm{~g}$ while between months 2 and 3 , the values were $0.01,0.02,0.06,0.06$ and $0.15 \mathrm{~g} / 100 \mathrm{~g}$ for millet, millet-cowpea, milletsoybean, millet-cowpea malt and millet-soybean malt respectively. The total moisture absorbed were 3.79, $4.36,4.02,4.15$ and $4.17 \mathrm{~g} / 100 \mathrm{~g}$ while the final moisture contents were $10.33,10.49,10.45,10.43$ and 10.61 for $\mathrm{M}, \mathrm{MC}, \mathrm{MS}, \mathrm{MC}_{\mathrm{m}}$ and $\mathrm{MS}_{\mathrm{m}}$ respectively.

\subsection{Crude protein}

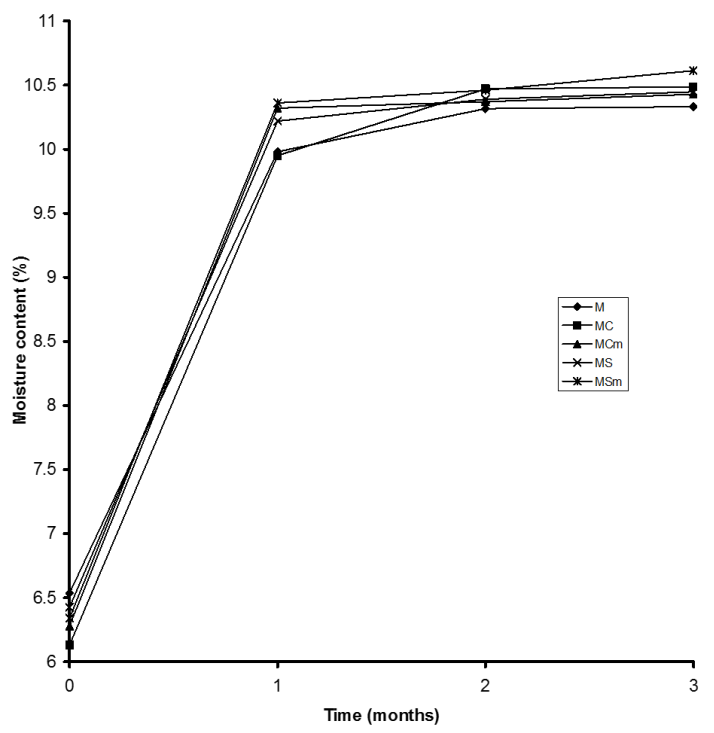

Figure 1. Moisture content of millet-cowpea and soybean blends stored for 3 months. M-millet; C-cowpea; $\mathrm{C}_{\mathrm{m}}$-malted cowpea; S-soybean; $\mathrm{S}_{\mathrm{m}-}$ malted soybean

Millet had a crude protein content of $10.09 \%$ while MC had $11.70 \%$, MS (18.44\%), $\mathrm{MC}_{\mathrm{m}}(16.62 \%)$, while in $\mathrm{MS}_{\mathrm{m}}$, it was $18.36 \%$. During the 90 -day storage period, protein contents decreased to $9.85 \%, 15.56 \%$ and $17.07 \%$ in flours from millet $(\mathrm{M}), \mathrm{MC}_{\mathrm{m}}$ and $\mathrm{MS}_{\mathrm{m}}$ while it increased to $12.26 \%$ and $19.94 \%$ in $\mathrm{MC}$ and $\mathrm{MS}$ respectively (Figure 2).

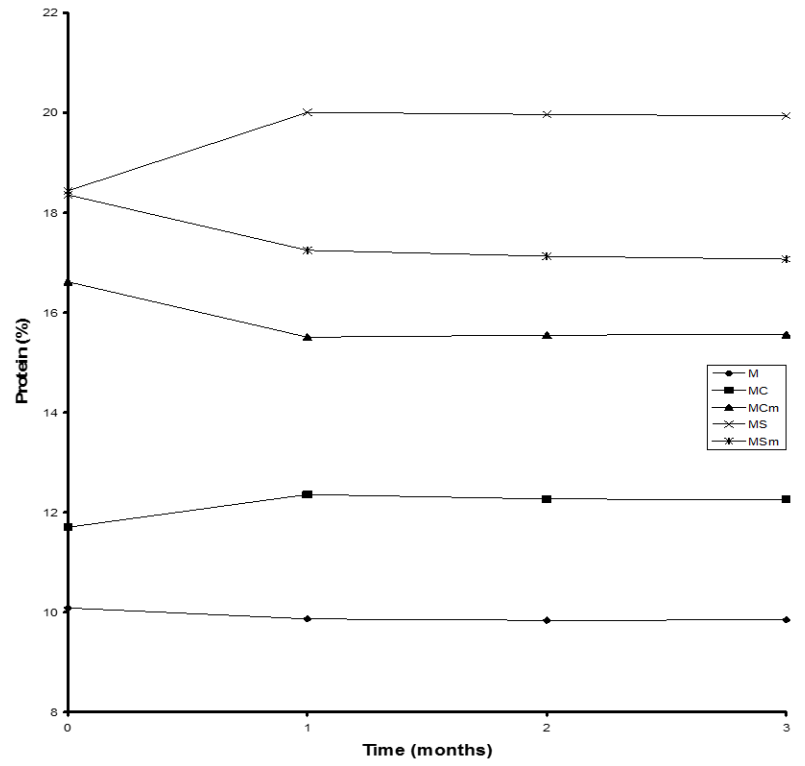

Figure 2. Protein content of millet-cowpea and soybean blends stored for 3 months. M-millet; C-cowpea; $\mathrm{C}_{\mathrm{m}}$-malted

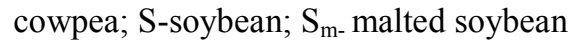

\subsection{Sugar content}

Millet had the highest sugar content of 3.54\%, while millet-cowpea (MC) had 2.77\%, millet-soybean (MS = $3.27 \%), \mathrm{MC}_{\mathrm{m}}=2.63 \%$ and $\mathrm{MS}_{\mathrm{m}}=3.09 \mathrm{~g} / 100 \mathrm{~g}$. Sugar content in all the samples increased with storage time (Figure 3); $\mathrm{M}$ increased by $1.98 \%$, MC (27.08\%), MS 
(4.59\%), $\mathrm{MC}_{\mathrm{m}}(28.90 \%)$ and $\mathrm{MS}_{\mathrm{m}}$ by $11.33 \%$. The final sugar contents were 5.52, 3.52, 3.42, 3.39, and 3.44 $\mathrm{g} / 100 \mathrm{~g}$ for $\mathrm{M}, \mathrm{MC}, \mathrm{MS}, \mathrm{MC}_{\mathrm{m}}$ and $\mathrm{MS}_{\mathrm{m}}$ respectively.

\subsection{Fat content}

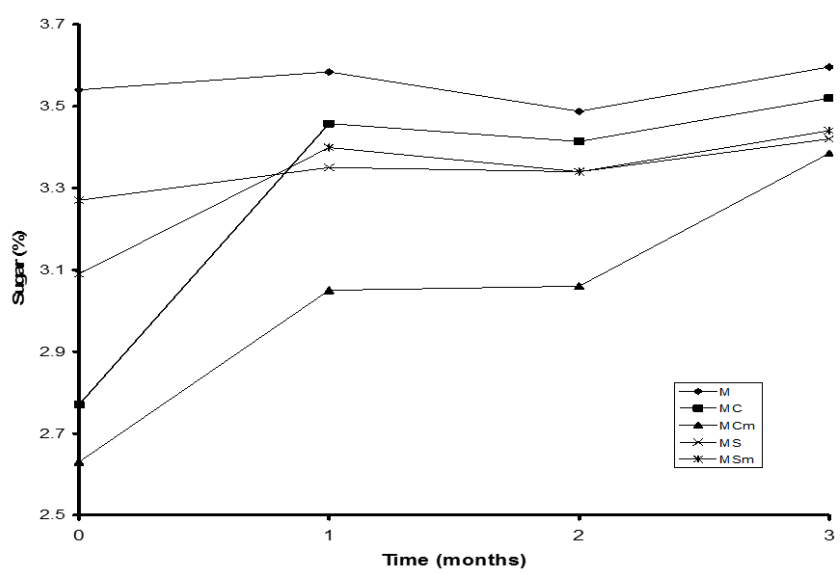

Figure 3. Sugar content of millet-cowpea and soybean blends stored for 3 months. M-millet; C-cowpea; $\mathrm{C}_{\mathrm{m}}$-malted cowpea; $\mathrm{S}$-soybean; $\mathrm{S}_{\mathrm{m}-}$ malted soybean

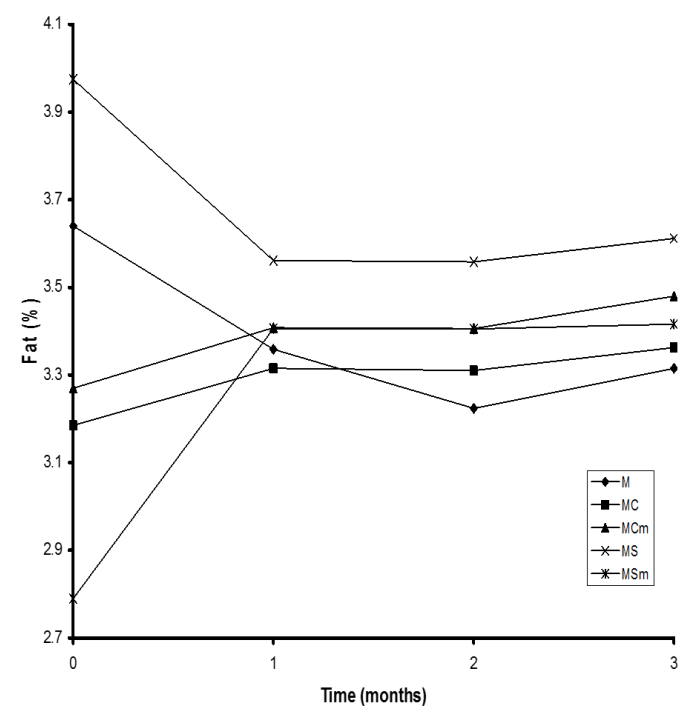

Figure 4. Fat content of millet-cowpea and soybean blends stored for 3 months. M-millet; C-cowpea; $\mathrm{C}_{\mathrm{m}}$-malted cowpea; S-soybean; $\mathrm{S}_{\mathrm{m} \text { - }}$ malted soybean

The fat content of millet $(3.64 \%)$ decreased on blending with cowpea (MC) to $3.19 \%$; but in the soybean blend (MS), it increased to $3.98 \%$ (Figure 4). The blend with malted cowpea $\left(\mathrm{MC}_{\mathrm{m}}\right)$ and malted soybean $\left(\mathrm{MS}_{\mathrm{m}}\right)$ had fat contents of $3.27 \%$. During the 3 months of storage, fat contents decreased in M and MS by 0.32 and $0.37 \%$ but it increased in $\mathrm{MC}, \mathrm{MC}_{\mathrm{m}}$ and $\mathrm{MS}_{\mathrm{m}}$ by 0.17 , 0.21 and $0.45 \%$ respectively.

\subsection{TBA content}

Millet had a TBA content of $0.0003 \mathrm{mg} / 100 \mathrm{~g}$ (Figure $5)$, which increased on blending with cowpea ( $\mathrm{MC}=$ $0.0005 \mathrm{mg} / 100 \mathrm{~g}$ ) and soybean (MS $=0.0004 \mathrm{mg} / 100 \mathrm{~g}$ ).
In the blends containing the respective malts, $\mathrm{MC}_{\mathrm{m}}$ had $0.0002 \mathrm{mg} / 100 \mathrm{~g}$ while $\mathrm{MS}_{\mathrm{m}}$ had $0.0003 \mathrm{mg} / 100 \mathrm{~g}$. On storage for 3 months, the TBA content of millet (M) flour remained unchanged; the values for MC and MS decreased within the first 2 months and then increased between the second and third months. The TBA values in $\mathrm{MC}_{\mathrm{m}}$ and $\mathrm{MS}_{\mathrm{m}}$ increased consistently during the storage period; the final values were $0.0003 \mathrm{mg} / 100 \mathrm{~g}$ for millet and 0.0004 for $\mathrm{MC}, \mathrm{MC}_{\mathrm{m}}, \mathrm{MS}$ and $\mathrm{MS}_{\mathrm{m}}$.

\section{Discussion}

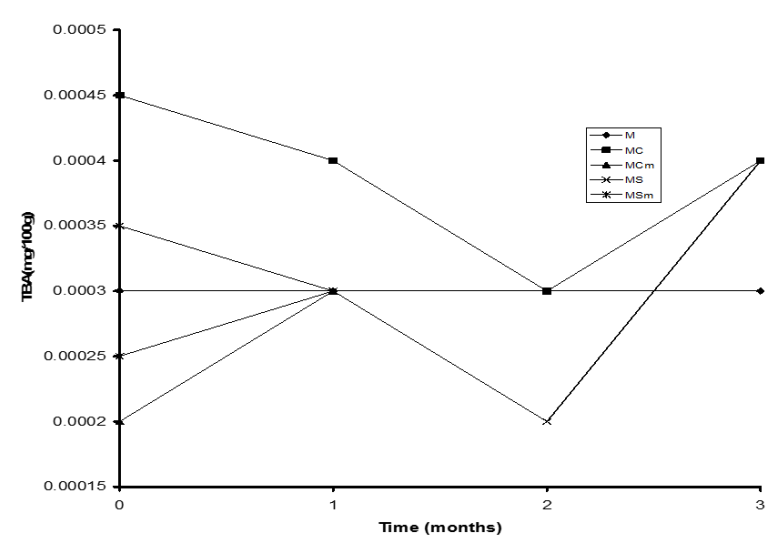

Figure 5. TBA content of millet-cowpea and soybean blends stored for 3 months. M-millet; C-cowpea; $\mathrm{C}_{\mathrm{m}}$-malted cowpea; $\mathrm{S}$ -soybean; $\mathrm{S}_{\mathrm{m} \text { - }}$ malted soybean

\subsection{Moisture}

The highest moisture content of $6.55 \%$ in millet flour compared to millet-soybean malt $\left(\mathrm{MS}_{\mathrm{m}}\right)$ and milletcowpea malt $\left(\mathrm{MC}_{\mathrm{m}}\right)$ flour blends (Figure 1) suggests that the water binding properties is associated with the carbohydrate (starch) fraction (Hendrickx et al., 1986). The further decrease in moisture content observed in millet-cowpea malt $\left(\mathrm{MC}_{\mathrm{m}}=6.23 \%\right)$ and millet-soybean malt $\left(\mathrm{MS}_{\mathrm{m}}=6.34 \%\right)$ could be due to the increasing amount of soluble matter resulting from the activities of hydrolases generated in the legume malts.

On storage, the moisture content of all the samples increased due possibly to the relative humidity of the environment and the water permeability of the polypropylene packaging material. The amount of moisture absorbed between months decreased with storage time suggesting a progressive saturation of the water binding sites. For millet, it decreased from 3.45 $\mathrm{g} / 100 \mathrm{~g}$ (month 0 to 1 ) to $0.01 \mathrm{~g} / 100 \mathrm{~g}$ between months 2 and 3 . This trend generally applied to all the samples.

In the cowpea (MC) and soybean (MS) blends, MC absorbed more water (4.36\%) than MS (4.02\%) probably because of the higher content of unmodified carbohydrates. But in $\mathrm{MCm}$ and $\mathrm{MS}_{\mathrm{m}}, \mathrm{MS}_{\mathrm{m}}$ absorbed 
more water $(4.25 \%)$ and had higher moisture content $(10.61 \%)$ than $\mathrm{MC}_{\mathrm{m}}(4.202 \% ; 10.43 \%)$ due possibly to the presence of a higher protein content. Similar results were reported by Afoakwa (1996).

\subsection{Crude protein}

The higher crude protein $11.07 \%$ in $\mathrm{MC}$ and $18.44 \%$ in MS compared to the $10.09 \%$ of millet suggests that cowpea and soybeans have higher protein content (SefaDedeh et al., 2000; Pamplona and George, 2004). In the samples containing malted legumes, $\mathrm{MC}_{\mathrm{m}}$ had a protein content of $16.62 \%$ (compared to MC with $11.07 \%$ protein) which is in line with increases in protein content during malting (germination). But in $\mathrm{MS}_{\mathrm{m}}$, it decreased to $18.36 \%$ (compared to MS with $18.44 \%$ protein) suggesting that more endosperm protein was utilized during germination than was synthesized de novo. During the 90-day storage period, the crude protein contents decreased in flours from millet $(\mathrm{M}), \mathrm{MC}_{\mathrm{m}}$ and $\mathrm{MS}_{\mathrm{m}}$ while it increased in MC and MS (Figure 2). The decrease in crude protein contents may be associated with the progressive formation of Maillard reaction products (Ramamani et al., 1996) which would be higher in the malted blends while the increase in MC and MS may be relative - resulting from decreases in the fat content, etc.

\subsection{Sugar content}

The highest sugar content of $3.54 \%$ in millet (M) flour probably resulted from its high residual diastatic activity of 600L (Figure 3) or from sugars formed during the growth of the crop. Partial substitution with cowpea $(\mathrm{MC}=2.77 \%)$ and soybean $(\mathrm{MS}=3.27 \%)$ showed that cowpea and soybean had lower residual diastatic activities. The sugar content further decreased on substitution with malted cowpea $\left(\mathrm{MC}_{\mathrm{m}}=2.65 \%\right)$ and soybean $\left(\mathrm{MS}_{\mathrm{m}}=3.09 \%\right)$ suggesting that sugars produced during germination were utilized to a greater extent in cowpea malt $(\mathrm{Cm})$ than in soybean malt $(\mathrm{Sm})$.

Sugar content in all the samples increased with storage time due to the residual amylolytic activities and increase in moisture contents of the flour samples. The highest amounts of sugar were produced between months 0 and 1 probably because of an active diastatic activity, while the least was produced between months 1 and 2 due possibly to dilution by the increased moisture content. The highest percentage increase in sugar content after storage was $28.9 \%$ for $\mathrm{MC}_{\mathrm{m}}$ and $11.33 \%$ for $\mathrm{MS}_{\mathrm{m}}$ which may be a reflection of the improved diastatic activities in cowpea and soybean malts.

\subsection{Fat content}

The fat content of M (3.64\%) was higher than MC $(3.19 \%)$ but was lower than MS which had a value of $3.98 \%$ (Figure 4). This may be attributed to the higher fat content of soybean $(19.9 \mathrm{mg} / 100 \mathrm{~g})$ compared to the $0.85 \mathrm{mg} / 100 \mathrm{~g}$ of cowpea (Pamplona and George, 2004). In the malted cowpea and soybean blends $\left(\mathrm{MC}_{\mathrm{m}}, \mathrm{MS}_{\mathrm{m}}\right)$, the fat content was $3.27 \%$. Malting is known to increase lipase activity (Uvere and Orji, 2002) which may suggest that lipase activity was higher in malted soybean compared to cowpea malt and could explain the decrease in the fat content of $\mathrm{MS}_{\mathrm{m}}$. The increase in the fat content of $\mathrm{MCm}$ could be due to the synthesis of oleosins during germination of cowpea.

Fat content decreased with storage time in $\mathrm{M}$ and MS due possibly to peroxidation reactions. It, however, increased in $\mathrm{MC}, \mathrm{MC}_{\mathrm{m}}$ and $\mathrm{MS}_{\mathrm{m}}$ because of the relative decreases in the contents of proteins and carbohydrates.

\subsection{TBA content}

Millet had a TBA content of $0.0003 \mathrm{mg} / 100 \mathrm{~g}$ (Figure 5), while MC had a value of $0.0005 \mathrm{mg} / 100 \mathrm{~g}$, MS had $0.0004 \mathrm{mg} / 100 \mathrm{~g}$ but the respective malt blends had lower values $\left(\mathrm{MC}_{\mathrm{m}}=0.0002 \mathrm{mg} / 100 \mathrm{~g} ; \mathrm{MS}_{\mathrm{m}}=\right.$ $0.0003 \mathrm{mg} / 100 \mathrm{~g})$. The higher TBA values in the unmalted blends represent a higher content of oxidation potential in cowpea compared to soybean. The decreases in the TBA values for the malt blends $\left(\mathrm{MC}_{\mathrm{m}}\right.$ and $\left.\mathrm{MS}_{\mathrm{m}}\right)$ suggest that malting produces substances which sequester the TBA or that the oxidation potential and TBA were mobilized during germination.

During storage for 3 months, the TBA content of millet (M) flour remained constant possibly arising from low residual lipase activity or unsaturated fatty acid content or that the conditions (lipoxygenase, the presence of copper, iron and oxygen) necessary for fat oxidation did not exist in the packaged flours. In MC and MS, the TBA values decreased within the first 2 months suggesting that conditions for initiation of auto-oxidation were lacking or that TBA reacting substances progressively formed complexes with other compounds in the blends. The subsequent steep increases between the 2nd and 3rd month suggest a number of possibilities: oxygen migration into the packages or activation of lipase activities although only MS had a higher value above the value at 0 time.

In $\mathrm{MC}_{\mathrm{m}}$ and $\mathrm{MS}_{\mathrm{m}}$, the TBA values increased suggesting the presence of lipase activity and/or the conditions necessary for oxidation. The increases in the 
TBA values further suggest that endosperm degradation during malting of the cowpea and soybeans may have exposed fat globules (oleosins) to hydrolysis and subsequent oxidation. Although all the blends had a final value of $0.0004 \mathrm{mg} / 100 \mathrm{~g}$, the malted blends showed a higher potential for increased TBA production if stored beyond 3 months.

\section{Conclusion}

The study has revealed that a 90 days storage of instant Kunun zaki flours in flexible packaging material at ambient temperature resulted in an increase in the chemical parameters except for protein which decreased hence there would need to use a better material for storage. However, the moisture contents of the blends and the final TBA values were low $\left(6.23 \%\right.$ for $\mathrm{MC}_{\mathrm{m}}$ and $6.34 \%$ for $\mathrm{MS}_{\mathrm{m}}$ and $0.0004 \mathrm{mg} / 100 \mathrm{~g}$ ) which contributed to some degree of stability in chemical properties. The best product was $\mathrm{MS}_{\mathrm{m}}$ because its moisture, fat and protein contents were more stable during storage compared to that of $\mathrm{MC}_{\mathrm{m}}$. Therefore, it is more likely to store for a longer period than $\mathrm{MC}_{\mathrm{m}}$.

\section{Declaration of Interest}

The authors declare that we have no conflicts of interest.

\section{References}

Adeyemi, T. and Umar, S. (1994). Effect of method of manufacture on quality characteristics of Kunun zaki, a millet based beverage. Nigerian Food Journal, 12, 34-41.

Afoakwa, E.O. (1996). Storage characteristics and quality evaluation of cowpea-fortified traditional foods. Legon, Ghana: University of Ghana, BSc Dissertation.

Duncan, D.M. (1995). Multiple Range and Multiple FTest. Biometrics, 11, 1-42.

Effiuvwewere, B.O and Akoma, A.O. (1995). The microbiology of Kunun zaki, a cereal beverage from Northern Nigeria during the fermentation (production) process. World Journal of Microbiology and Biotechnology, 11, 491-493.

Gaffa, T. and Ayo, J.A. (2002). Innovations in the traditional Kunun zaki production process. Pakistan Journal of Nutrition, 15, 202-205.

Haard, N.F. (1998). Fermented cereals, a global perspective. Technology and Engineering.

Hendrickx, M., Engels, C., Tobback, P. and Johns, P. (1986). Transmission line modelling (TLM) of water in white rice. Journal of Food Engineering, 5, 269286.

Kirk, R.S. and Sawyer, R. (1991). Pearson's composition and analysis of foods. $9^{\text {th }}$ ed. UK: Longman Group Ltd

Osuntogun, B. and Aboaba, O.O. (2004). Microbiological and physico-chemical evaluation of some non-alcoholic beverages. Pakistan Journal of Nutrition, 3(3), 188-192.

Pamplona, R. and George, D. (2004). Encyclopedia of Foods and their Healing Power (A guide to Food Science and Diet Therapy). Vol. 2, p. 264-273. Madrid: Editorial Safeliz

Radley, J. (Ed). (1976). Examination and analysis of starch and starch products. London: Applied Science Publishers.

Ramamani, S., Chandrasekhara, H.N. and Narasimba, M.K. (1996). Efficiency of inactivation of trypsin and haemaglutinins by roasting of soybean (Glycine max). Journal of Food the Science and Technology, 33, 197-201.

Sefa-Dedeh, S., Frimpong, K., Afoakwa, E.O. and SakyiDawson, E. (2000). Cowpea fortification of traditional foods. Presented at the World Cowpea Research Conference III, September 2000, p. 4-7. Ibadan, Nigeria

Tarladgis, B.G., Watts, B.M., Younathan, M.T. and Ougan, L. (1960). A distillation method for the quantitative determination of malonaldehyde in rancid foods. Journal of American Oil Chemists Society, 37, $44-78$.

Uvere, P.O. and Orji, C.S. (2002). Lipase activities during malting and fermentation of sorghum for burukutu production. Journal of the Institute of Brewing, 108(2), 256-260.

Uvere, P.O. and Amazikwu, U.C J. (2011). Processing and evaluation of instant Kunun zaki from milletcowpea malt and millet-soybean malt. African journal of Food Science, 5(14), 761-768. https: // doi.org/10.5897/AJFS11.069.

Uvere, P.O., Ozioko, A. and Bechem, M.E. (2011). Effect of malting on the chemical composition of cowpea (Vigna unguiculata) and soybeans (Glycine max) seeds. Nigerian Journal of Nutritional Science, 32(2), 17-21. 